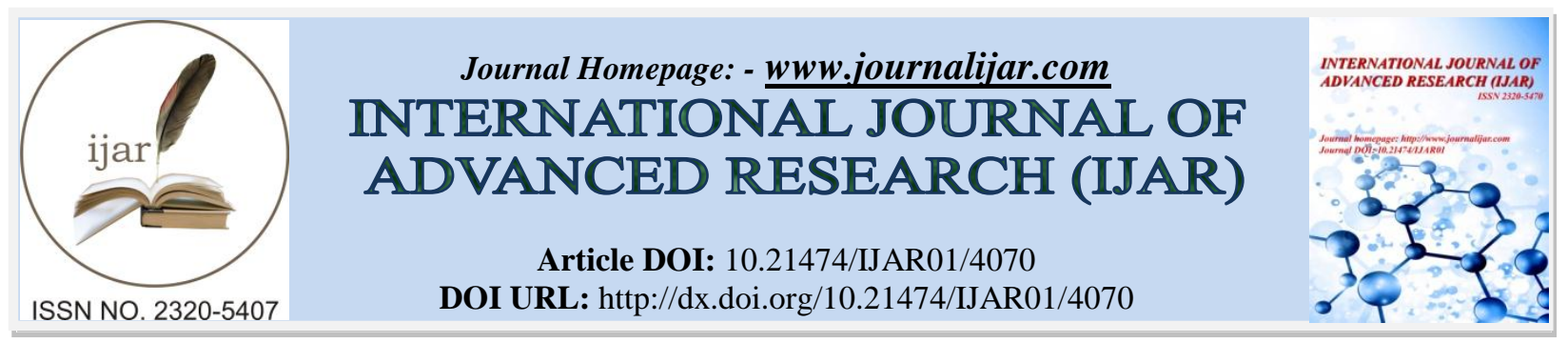

CASE REPORT

\title{
HYPOPITUITARISM WITH GROWTH HORMONE DEFICIENCY.
}

Dr.L.Santhanalakshmi, M.D.,D.G.O,M.B.A.

\section{Manuscript Info}

Abstract

Manuscript History

Received: 19 February 2017

Final Accepted: 20 March 2017

Published: April 2017

Copy Right, IJAR, 2017,. All rights reserved.

\section{Introduction:-}

Mr. Dhinesh aged 11 years, first sibling born as a fullterm baby which cried immediately after birth got registered (20883 M, Child ) in Endocrinology Outpatient Department, Government Rajaji Hospital attached to Madurai Medical College, Madurai on 20.07.2011 (EC 2848 ) with H/O growth retardation, somnambulism, easy fatiguability, poor memory, poor performance at school and no $\mathrm{H} / \mathrm{O}$ anosmia. His vitals were normal. He was provisionally diagnosed as Hypopituitarism with Growth Hormone deficiency.

On clinical Examination, patient was short statured, obese with a height of $144.5 \mathrm{cms}$ and weighing $58.8 \mathrm{kgs}$ with BMI 16.24. Conscious, well oriented. Clinical examination of CNS, CVS, RS, Abdomen were normal except for small genitalia. Inguinal region was free. Testicular volume $<4$ cubic centimetres. Hypoplastic with loss of rugosity.

Investigation revealed:-

Visual examination revealed High Myopia and is wearing corrective glasses.

Urine-acidic 7.

Blood:

Hb- 9.3 gms / dl.

Differential count ; P 44\%, L $50 \%$, E $6 \%$.

ESR $14 \mathrm{~mm}$ at the end of 1 hour.

Platelets 2.78 lakh / cu mm.

PCV- $47.7 \%$.

BT- 2 min $45 \mathrm{sec}$

CT- 6 min.

\section{Hormonal Assay:}

T3 $0.79 \mathrm{ng} / \mathrm{ml}$

T4 $6.20 \mu \mathrm{g} / \mathrm{dl}$

TSH $0.53 \mu \mathrm{iu} / \mathrm{ml}$

Growth Hormone $0.15 \mathrm{ng} / \mathrm{ml}$.

FSH $0.89 \mu \mathrm{iu} / \mathrm{ml}$

LH $0.17 \mu \mathrm{iu} / \mathrm{ml}$

Prolactin $1.65 \mathrm{ng} / \mathrm{ml}$.

Xray skull revealed no abnormality. No calcification in pituitary region.

MRI not done. 
Patient was provisionally diagnosed as Hypogonadism, Hypopituitarism with ? Growth Hormone Deficiency.

Patient was treated with

Injection Pubergen ( hCG ) 1000 iu subcutaneously daily at night for 1 month.

Tab Thyroxine $100 \mu \mathrm{g} / \mathrm{dl}$.

Tab. Menobal $20 \mathrm{mg} / \mathrm{od}$.

Tab. Restore $25 \mathrm{mg} /$ day.

\section{Discussion:-}

Impaired synthesis of one or more anterior pituitary hormones may result from heritable genetic factors, acquired anatomic insults, inflammations, vascular damage etc.,

Hypogonadotropic Hypogonadism may result from Hypothalamic or Pituitary defects. FSH is required quantitatively for normal spermatogenesis. Low LH levels in these patients lead to low intratesticular testosterone concentrations with decreased spermatogenesis.

Gonadotropin deficiency causes hypogonadism with decreased sex steroid production of varying degree, depending on the severity of the insult. In this patient, it was prepubertal in onset with a reduction in Testicular volume, hypoplastic with no rugosity with a short penis. Voice pitch was normal.

Mammosomatotroph cells expressing both PRL and GH arise from the acidophilic stem cells of Pituitary. Multiple factors regulate the integrated secretion of GH. $70 \%$ of daily $\mathrm{GH}$ secretion occur with the first episode of slow wave sleep Van Cauter. Growth hormone deficiency in children is typically isolated GHD or from rare genetic causes or central structural abnormalities.

Because the half life of serum T4 is 6.8 days, hypothyroidism may not become apparent for several weeks in patients with acute pituitary insufficiency. TSH is not elevated in secondary hypothyroidism. It cannot be used to assess the adequacy of Thyroid Hormone Replacement.

Prolactin deficiency is extremely rare.

\section{Conclusion:-}

In evaluating Hypogonadism in the absence of obvious Pituitary disorders, a constitutional pubertal delay should be ruled out from Hypogonadotropism McCullah. When puberty is delayed beyond 14 years of age, a primary developmental disorder, Hypogonadotropic Hypogonadism or acquired disorders of reproductive function to be considered Anawalt et al.

No single test clearly distinguishes constitutional delayed puberty from Hypogonadotropism. The insulin tolerance test has remained the 'Gold Standard Test' for GHD Williams.

A close and expectant follow up is essential to look for this patient whether he is entering puberty spontaneously or Delayed puberty associated with insufficient gonadotropic pituitary function. Sterility due to deficient spermatogenesis has to be looked upon at a later stage.

Life expectancy is reduced in hypopituitary patients with Growth Hormone Deficiency Rosen et al.

As the patient did not report Endocrinology OPD, a delay in pinpointing the actual diagnosis gets delayed.

\section{Bibliography:-}

1. McCullah DR, Dual endocrine activity of the Testes- Science 1932; 76;19-23.

2. Anawalt BD, Bremner WJ, Diagnosis and treatment of male gonadotropin insufficiency. In Lamberts SW ( ed ) The Diagnosis and Treatment of Pituitary Insufficiency. Bristol, UK, Bio Scientifica, 1997, pp 163-207.

3. Bhasin S, Salehian B, Gonadotropin therapy of men with Hypogonadotropic Hypogonadism . Current Ther Endocrinol Metab 1997;6; 349-352.

4. Van cauter E, Plat L, Copinschi G, Interrelations between sleep \& the somatotropic axis. Sleep 1998; 21;553566.

5. Rosen T, Bengtsson BA, Premature mortality due to hypopituitarism. Lancet 1990; 336;285-285. 